\title{
Legal Support of the Patient's Right to Innovation in Health
}

\author{
Oleksandr Shevchuk ${ }^{1}$, Oleksandr Lysodyed ${ }^{2}$, Igor Borysenko ${ }^{3}$, Oleg Bululukov ${ }^{4}$, \\ Oleksandra Babaieva ${ }^{5}$
}

\begin{abstract}
The article discusses certain aspects of legal regulation of patients' rights to innovations in healthcare sector. The subject of the study is the legislative acts on human rights in healthcare field, forms and types of human rights and directions for their implementation. Attention is focused on such types of patients' rights to innovations in healthcare field: (1) right to biomedical experiments; (2) right to reproductive technology; (3) right to donation;

(4) right to transplant organs and anatomical materials; (5) right to therapeutic cloning; (6) right to change gender; (7) right to virtual reality. Essence of "innovation in medicine" is revealed, classification of human rights is given.

The purpose of the article is to disclose the features of legal regulation of implementation of the patients rights to innovations in healthcare field. The methodology of this work is based on a set of research methods. The comparative method was used to elucidate the legal aspects of the patients rights to innovations in healthcare sector. Using the method of theoretical analysis, systemic and analytical methods, the term "patients' rights to innovations in healthcare field" was established, their varieties were characterized. Introduction of effective innovative models in health sector in context of patient rights will improve the availability and quality of provision of medical services to the population. It has been established that an important element in the implementation of innovative technologies in healthcare sector is the regulatory framework, which must comply with international standards.
\end{abstract}

Key words: health sector, innovation, legal regulation, patient rights.

\section{Introduction}

In modern realities, the healthcare sector of Ukraine most of all needs effective transformations and innovations, since it must support the satisfaction of citizens' needs for high-quality and affordable medical services. Ukraine is dominated by a critically low level of government spending on ensuring and protecting the health of each individual citizen. In June 2014, an Association Agreement was signed between Ukraine and the European Union, the European Atomic Energy Community and their member states. In accordance with the Agreement, one of the planned reforms was the medical reform, the

\footnotetext{
1'Doctor of Law sciences, Professor of the Department of Administrative Law and Administratively Activities, Yaroslav Mudryi National Law University, Kharkiv, Ukraine.

${ }^{2} \mathrm{PhD}$ in Law, associate professor, Associate Professor of Department of Criminology and Criminal Executive Law, Yaroslav Mudryi National Law University, Ukraine

${ }^{3} \mathrm{PhD}$ in Law, associate professor, Associate Professor of Department of Criminalistics, Yaroslav Mudryi National Law University, Kharkiv, Ukraine.

${ }^{4} \mathrm{PhD}$ in Law, associate professor, Associate Professor of Department of Criminalistics, Yaroslav Mudryi National Law University, Kharkiv,Ukraine.

5 PhD in Law, Assistant Department of Criminal Process and Operative Search Activity, Yaroslav Mudryi National Law University, Kharkiv, Ukraine.
} 
foundations of which are laid in the obligations of Ukraine: oriented improvement of the level of health protection; strengthening the health care system of Ukraine and its potential. It should be noted that to a certain extent in Ukraine there is an emphasis on the use of budgetary instruments to stimulate the development of innovations in the healthcare sector, but such support is insignificant and ineffective.

The basis for increasing the medical, social and economic efficiency of the functioning of the healthcare system is the rational implementation of innovative technologies for the treatment, diagnosis, prevention and rehabilitation of diseases, improving the management and training of medical personnel in healthcare institutions. The innovative process in healthcare field is the key to the effective functioning of healthcare facilities, achieving general medical goals and ensuring timely care for patients [11].The healthcare sector of Ukraine most of all needs the effectiveness of transformations and innovative projects, as it must support the satisfaction of the needs of citizens in quality and affordable medical services. The above indicates the relevance of this work.

\section{Literature review}

The issue of innovation in the field of healthcare was also studied by foreign scientists. So, Juma, C. (2010) investigated a system of innovations in healthcare in Africa, which is distinguished by a combination of local research, entrepreneurship and institutional adaptation [16]. Bayram, M., et all. (2020) drew attention to the problem of COVID-19 regarding innovation policy in the field of digital health[6]. Kela-Madar, N. et all., (2019) indicated that innovative technologies have the potential to solve health problems. The authors used big data analysis based on artificial intelligence and machine learning, and concluded that it is possible to increase the efficiency of the use of medical drugs in the healthcare sector when new medical technologies are introduced to the market [17]. Allen, L. N. et all., (2016) studied personalized healthcare technologies, such as fitness trackers and healthy lifestyle apps, designed to help users quantify and improve their health behavior [5].

The assertion of the human right to innovation in Ukraine occurs through the legislative consolidation of social relations, as well as as a result of the formation and development of relevant legislation. We also note that the scientific literature has not yet focused enough attention on disclosing the issues of legal regulation of patients' rights to innovations in the healthcare sector, as well as improving their legal regulation. In addition, in the national legislation, the specifics of the content of the right to innovation have not been exhaustively studied, since neither the Constitution of Ukraine, nor the "Fundamentals of Ukrainian legislation on health care" identify specific powers of this right, and in the scientific community there are significant discrepancies. Therefore, it is necessary to create and form a unified regulatory space for the development of investments in the healthcare sector with the consolidation of forces and means, as well as compliance with the principles of their intended purpose, territorial accessibility and social justice. However, the issue of patient access requires more attention regarding the optimization of the system of innovative factors and the development of the regulatory framework in this area. 


\section{Methodology and research methods}

The methodological basis of the scientific article on the rights of the patient to innovations in the healthcare sector was a combination of general philosophical, general scientific and special legal methods. These methods were used in this work, namely, system-functional analysis, dialectical, formal-logical and hermeneutic methods. Using the legal analysis, systemic and analytical methods, the legal structure "the patient's right to innovate in healthcare" was determined and the specifics of its legal regulation were established. The purpose of the article is to disclose the features of legal regulation of implementation of the patients rights to innovations in healthcare field. According to the stated goal of the article, its main tasks are: (1) to determine the main international legal acts and acts of national legislation governing legal relations arising in the process of exercising patients' rights to innovations in the health care sector;

(2) provide a description of the elements of the content of patients' rights to innovations in the health sector; (3) to disclose international legal standards for patients' rights to innovations in healthcare; (4) to propose the author's classification of patients 'rights to innovations in the healthcare sector; (5) to develop proposals for improving the legal framework for the implementation of patients' rights to innovations in healthcare.

\section{The essence of the concept "the patient's right to innovate in the field of healthcare"}

Innovation is a new branch of science, now its scientific and practical formation and development is taking place, the beginning of which scientists determine from the beginning of the twentieth century. Innovation in the field of protection represents complex measures aimed at implementing the implementation of the innovation process of the healthcare system. Relations in the field of healthcare are developing on the basis of legal norms, within the framework of the current national legislation. Therefore, innovative development in the healthcare sector is impossible without innovative development of law, without the development and formation of an innovative modern legal system. After all, the relationships that develop about human health are regulated norms of various branches of law (administrative, civil, labor, criminal law, etc.). The right to health category is a universal category that covers all legal prescriptions (both protective and regulatory) that exist in this area.

The legal system of Ukraine has already created the initial conditions for legal regulation of the innovative development of the healthcare sector. In the context of the development of medical reform and European integration processes in Ukraine, it is advisable to develop legal regulation of the mechanisms for the full realization of the patients' right to innovations in the healthcare sector. The modern national legislation of Ukraine is characterized by the absence of a single special legislative act that would regulate the rights of patients in the field of healthcare.The legislation of Ukraine on the patient's rights to innovations in health care consists of the relevant provisions of the Constitution of Ukraine, the Fundamentals of Ukrainian legislation on health care, other legislative and regulatory legal acts of Ukraine regulating relations in the field of ensuring and protecting the patient's rights. Ukrainian legislation defines health as a state of 
complete physical, mental and social well-being, and not just the absence of disease and physical defects (Art. 93) [14].

It is also necessary to distinguish between the following areas of ensuring human rights in the field of medical activity: regulatory legal (creation of legal documents containing mechanisms for the implementation of citizens' rights); organizational (creating conditions under which it becomes possible to exercise the rights of citizens); financial and economic (increase in health care costs in the budgets of various levels, implementation of targeted programs); informational (mass media activities aimed at informing citizens about their rights)[28]. We will focus on the legal and regulatory directions of ensuring human rights to innovation in the healthcare sector.

According to the International Convention for the Protection of Human Rights and Fundamental Freedoms of November 4, 1950: States are responsible for the health of their peoples, and this responsibility requires the implementation of appropriate social measures in the field of health. The concept of health care development for the population of Ukraine, approved by the Decree of the President of Ukraine dated December 7, 2000, provides: the state policy in the field of health care is aimed at improving health, improving the quality of life and preserving the gene pool of the Ukrainian people. The WHO concept "Health'2020: a framework for a European policy and strategy for the 21st century" defines the main goals of the functioning of the health system, these include: improving the health of the entire population, meeting the needs and demands of people. A prerequisite for this is the creation and successful operation of a regulatory and legal framework that includes a complex of all resources, including technology innovation.

According to the constitutional definition of Ukraine as a social state, the policy of which is aimed at creating conditions for ensuring a decent standard of living for a person and the provisions of Art. 49 of the Constitution of Ukraine, according to which the duty of the state is to ensure the right of citizens to health protection. In accordance with Article 3 of the Constitution of Ukraine, a person, his life and health, honor and dignity, integrity and security are recognized in Ukraine as the highest social value. Not a single person can be subjected to medical, scientific or other experiments without his voluntary consent (part 3 of art. 28)[9]. The Law of Ukraine "About Priority Directions of Innovation Activities in Ukraine" defines the legal, economic and organizational found ations for the formation of an integrated system of priority directions of innovation activity and their implementation in Ukraine [4]. This law defines the priority areas of innovation in Ukraine: (1) scientifically and economically substantiated and defined in accordance with this Law, directions of production of innovative activities aimed at ensuring the economic security of the state, (2) the creation of high-tech competitive environmentally friendly products (3) the provision of high-quality services (4) an increase in the export potential of the state with the effective use of domestic and world scientific and technological achievements. The health sector is in the process of reforming both legislation and implementing modernization programs, among which the development and implementation of medical innovations are identified as one of the development priorities. The Law of Ukraine "Fundamentals of the Ukrainian Legislation on Health Care" states that the state promotes the development of scientific research in 
the field of health care and the implementation of their results in the activities of healthcare institutions and workers (art. 20) [14].

There is no single point of view among scientists on the term "innovations in medicine", and the definition of "the right of a patient to innovations in healthcare" has not been established. So, the concept of "innovation" is provided for in article 1 of the Law of Ukraine "About innovative activity". Under this term, the legislator understands how newly applied and (or) improved competitive technologies, products or services, as well as organizational and technical solutions of a production, administrative, commercial or other nature, which significantly improve the structure and quality of production and (or) social sphere. ) [3]. So, according to Gorban, A. E. (2015), "innovations in medicine" are original technologies for the production, use of medicines, medical devices, as well as new methods of diagnosis, treatment, prevention and rehabilitation[15]. From the point of view of Mochalov Yu (2014), "innovations in medicine" are new ideas, approaches, drugs or diagnostic methods or techniques for interventions that are used in the provision of medical services (care) or in the organization of such processes that are perceived as new or possessing unique properties [21]. There is a point of view of scientists that "innovations in healthcare" are a product of activities related to the development of technologies in the field of medicine, scientific achievements and best practices aimed at obtaining qualitatively new models and technologies of healing, treatment, administering processes in the medical field, obtaining new medical products and services; and the "innovative development of the health care system" is an activity, the result of which is the improvement of existing and the development of new medical products (technology, equipment, programs or services) sold on the market, or the introduction of a new or improved process that is directly or indirectly used in practical medicine [29]. From our point of view, "the patient's right to innovate in the field of healthcare" is the human right to access to medical services, including diagnostic and therapeutic procedures and medicines that meet international standards, as well as the introduction of advanced methods of diagnosis, treatment and rehabilitation.

\section{Classification and characterization of the human right to innovation in the health sector}

Healthcare innovations are classified according to various criteria:

1. By type of activity: medical (which provide a treatment process, managerial (related to management in the health care system).

2. By the nature of the changes introduced: (a) combinatorial (which combine the corresponding elements); (b) radical (based on fundamentally new complexes of actions); 3. By the scale of use: (1) single (carried out once); (2) diffuse; (3) repetitive.

4. In terms of the scale of the changes introduced: (1) modular (including interconnected groups of several local innovations in the health care system) (2) systemic, based on a complete reconstruction of the system as a whole.

5. By duration: short-term and long-term.

6. By methods of implementation: (1) administrative (2) liberal (3) authoritarian (4) initiative. 
7. Depending on the area of implementation: in the health care system; in the structure of interaction between participants in the health care system.

8. Depending on functionality:

- innovations (conditions - provide an effective health care process;

- innovations (new product - medical equipment, equipment, etc.);

- organizational and managerial innovations (qualitatively new solutions in managerial procedures that ensure their functioning).

9. Based on the intensity of innovative change or the level of innovation:

- zero-order innovation (this is practically regeneration):

- primary properties of the reproduction system of the traditional health care system or its element);

-innovations of the first order (characterized by quantitative changes in the system while its quality remains unchanged;

- second-order innovations (represent a regrouping of system elements and organizational changes;

- third-order innovations (adaptive changes in the health care system in new conditions without going beyond the old health care model;

- innovations of the fourth order (contain a new version of the solution (these are most often the simplest qualitative changes in individual components of the health care system, providing some expansion of its functionality)

- innovations of the fifth order (initiate the creation of a "new generation" health care system (changing all or most of the initial properties of the system);

- innovations of the sixth order (as a result of implementation, health care systems of a "new type" are created with a qualitative change in the functional properties of the system while maintaining the backbone functional principle);

- innovations of the seventh order (a radical change in the health care system, during which the basic functional principle of the system changes).

10. On the understanding of the implementation of innovations:

(1) accidental (innovations, contrived and introduced from the outside, not arising from the logic of the development of the healthcare system); (2) systemic (innovations derived from the problem field with clearly defined goals and objectives) [29].

According to the classification of human rights in the field of medical activity, the rights of patients are divided into: (1) general rights of patients and (2) the rights of patients in certain areas of medical activity (transplantology, psychiatry, immunoprophylaxis, etc.). In addition, it is proposed that health rights be divided according to the classification criterion - the subject of implementation. In accordance with it, basic, special and special human rights in the field of healthcare are distinguished [28]. According to another classification, four generations of human rights are distinguished. And the formation of the fourth generation of human rights is associated with scientific and technological progress, discoveries in medicine, biology, genetics, in the space sphere [25].

For example, Shebanitz D. M. (2015) ranked fourth-generation rights as the right to euthanasia, sex change, organ transplantation, the use of virtual information, and the right to clone [26]. Among the components of the fourth generation of human rights, somatic human rights are distinguished. Somatic rights are understood to mean a group 
of rights related to a person's ability to independently dispose of his body, carry out its "modernization", "restoration" and even "fundamental reconstruction", change the body's functional capabilities and expand them with technical-aggregate or medication (the right to dispose of the life of one's own body (euthanasia), determination of one's gender, the free disposal of one's reproductive function, the use of reproductive technologies, in particular artificial insemination and cloning, organ and tissue transplantation.[26]. Starovoitova O. E. (2006) relates to somatic rights: the right to transplant organs and tissues, the right to abortion, the right to clone, the right to artificial reproduction, the right to dispose of life and body [30].

There are different approaches to somatic human rights into: (1) the right to die (human freedom to voluntarily end his life in a way that was chosen and accessible to him (euthanasia or suicide)); (2) human rights with respect to his organs and tissues (transplantation, rights of donors and recipients); (3) sexual human rights; 4) reproductive human rights (positive - artificial insemination, negative - abortion, sterilization, contraception); 5) the right to change sex (from male to female and from female to male) [20]. Others indicate that the right to innovation includes: (1) the right to a biomedical experiment; 2) the right to reproductive technology; 3) the right to donation; (4) the right to therapeutic cloning; 5) the right to sex correction (change)[19], others indicates that "healthcare innovations" are the result of innovative activities implemented in the form of ensuring the modernization of the material and technical base of the industry, the introduction of advanced means and methods of treatment, medical technologies, medical devices and medicines, improvement existing diagnostic and treatment methods (medical innovations), the development of software for information processing, the creation of new models for the functioning of the sphere and the development of personnel that have an impact on improving public health, economic indicators of business entities of this segment [24]. The provisions of the European Charter on the Rights of Patients provide for the right to innovation: "Everyone, regardless of their financial situation, has the right to access to medical care, including diagnostic and therapeutic procedures and medicines that are in line with international standards" (art.10)[13]. Human rights to innovations in the health sector include: (1) the right to a biomedical experiment; (2) the right to assisted reproductive technologies; (3) the right to donate blood and its components; (4) the right to transplant organs and anatomical materials; (5) the right to therapeutic cloning; (6) the right to correct (change) sex; 7) the right to virtual reality. In the future, we consider some of them.

\subsection{Patient's right to a biomedical experiment.}

A biomedical experiment is a scientific research activity, the purpose of which is to save the life, improve or restore the health of a particular patient. This activity is aimed at improving public health and medicine in general, carried out by qualified scientists. A component of biomedical experiments is the clinical trials of drugs conducted to determine their safety, quality, effectiveness and efficacy [7]. The Law of Ukraine "Fundamentals of the Ukrainian Legislation on Health Care" defines that the use of biomedical experiments in humans is allowed for a socially useful purpose, provided that they are scientifically sound, the benefits of possible success over the risk 
of serious consequences for health or life, the publicity of the application of the experiment, full awareness and the voluntary consent of an adult capable individual to the experiment to be carried out and the requirements for its implementation, subject to medical confidentiality (Part 1 of Art. 45) [14]. It should be noted that the components of a biomedical experiment can be both clinical trials of drugs, and a medical experiment, a biological experiment, etc.

Clinical trials of drugs are a type of biomedical experiment in humans. The Law of Ukraine "On Medicines" notes that clinical trials of drugs are tests that are carried out to establish or confirm the efficacy and safety of the drug the funds that can be spent in medical institutions are determined by the central executive body that implements the state policy in the field of healthcare (Art. 7)[22]. In addition, the Civil Code of Ukraine provides for the possibility of conducting medical, scientific and other experiments only with an adult capable natural person by his free consent. A patient without his voluntary consent cannot be subjected to medical, scientific or other experiments (Part 3 of Art. 281)[8]. The Criminal Code of Ukraine provides for liability for violation of the rights of the patient that occurs if the above principles of conducting clinical trials are not followed, as well as when conducting illegal trials of a person (Art. 141 and 142)[10].

\subsection{Patient's right to reproductive technology.}

In order to determine the legal nature of reproductive rights, it should be noted that they are complex in nature and include a number of personal rights, which are enshrined in international legal documents on human rights and freedoms, in laws and other regulatory legal acts. The debatable issue is the legal nature of reproductive rights. Thus, reproductive rights are complex and are only derivatives of personal rights; they do not belong to natural rights, because they are a product of modern law; reproductive rights derive from a number of constitutional rights: the right to life, the right to health care, the right to state protection; reproductive rights are derived from the right to health. Adequate legal provision of the human right to use assisted reproductive technologies and associated reproductive rights is one of its guarantees. Such a factor as a decrease in the population of Ukraine is the basis for the formation of its own concept of reproductive rights, in which it is necessary to take into account the interests of the state and the nation, human rights and freedoms. There is a need to develop a legislative consolidation of reproductive rights, in one special legislative act, for example, "Human rights in the field of health care" as guaranteed, encouraged by the state, the possibility of procreation, reproduction of the population.

Thus, in 2015, the UN adopted 17 Sustainable Development Goals - the 2030 Agenda, as well as an updated Strategy for the protection of the health of women, children and adolescents for 2016-2030. Among other things, they touch upon issues related to the protection of reproductive rights and reproductive health. Human rights to reproductive reproduction, provided for by the Universal Declaration on Bioethics and Human Rights, adopted under the auspices of UNESCO on October 19, 2005, regulates ethical issues related to medicine, science, technology applied to humans. The fundamental principles of regulation of activities related to the human right to reproductive technologies are also enshrined. In particular, Article 16 provides for the protection of future generations, which states that the necessary attention should be paid to the impact 
of the life sciences on future generations, in particular on their genetic characteristics. Human rights to reproductive reproduction are also provided for by the Universal Declaration of Human Rights, adopted by the UN General Assembly in 1948, which enshrines the right to freedom from discrimination on the basis of sex (Art. 2); the right to respect for private and family life (art. 12); the right to marriage and family (art. 16); the right to abolish discriminatory practices against women in the matter of marriage, during marriage and at the time of its dissolution (art. 16). In the 1979 Convention on the Elimination of All Forms of Discrimination against Women, the right to reproductive technology is partially disclosed through the prism of motherhood and its protection (Articles 4, 5, 11, 12), and also enshrines the same rights of men and women to freely decide the number of children and the intervals between their birth and access to information, education, as well as the means that help them to exercise this right (Art. Art. 12, 16).

The Civil Code of Ukraine establishes that adult men and women have the right for medical reasons to conduct treatment programs for them with assisted reproductive technologies [8]. The Family Code of Ukraine proclaims that a woman has the right to motherhood (Art. 49), and a man has the right to fatherhood (Art. 50). The basic reproductive right is the right to free reproductive choice, creation and family planning. In Art. 4 of the Family Code of Ukraine states that a person who has reached marriageable age has the right to found a family. Persons applying for marriage registration must inform each other about their state of health (Art. 30). Article 3 of the Family Code of Ukraine notes that a family consists of persons who live together, are connected by a common way of life, have mutual rights and obligations. However, Part 2 of Art. 21 Family Code of Ukraine indicates that living in one family of a woman and a man without marriage is not the basis for the emergence of their rights and obligations as spouses. At the same time, Part 1 of Art. 74 of the Family Code of Ukraine regulates the regime of property acquired by a man and a woman who live in the same family, but are not married. It follows from the norms of the current family legislation of Ukraine that the application of the right to reproductive rights is determined only for spouses. Thus, persons who are in de facto marital relations are not included in the circle of possible subjects of legal relations in this aspect. [31]. That is, the right to reproduction is provided for at the legislative level. By definition of the World Health Organization, reproductive health is a state of complete physical, mental and social well-being, and not just the absence of diseases of the reproductive system or impaired function (World Health Organization, 2006)[32]. Based on the above, reproductive human rights include: (1) the right to free reproductive choice; (2) the right to access medical services for the protection and protection of reproductive health; (3) the right to health care (during pregnancy, during childbirth and after childbirth); (4) the right to infertility treatment; (5) the right to donate germ cells and preserve them; (6) the right to free choice of methods of contraception; (7) the right to surgical sterilization; (8) the right to artificial termination of pregnancy; (9) the right to make decisions during medical interventions related to reproductive health; (10) to protect their reproductive rights; (11) the right to privacy of information about reproductive rights[12]. 


\subsection{The right to therapeutic cloning.}

An important place among international documents is occupied by the UN Declaration on Human Cloning, which called for the prohibition of all forms of human cloning to the extent that they are incompatible with human dignity and the protection of human life, and to take measures necessary to prohibit the use of genetic engineering methods that may contradict human dignity.

There are two types of cloning. The first is human cloning, which in the legal literature is reproductive cloning, and the second is therapeutic cloning, which is permitted at the legislative level in some countries of the world. Reproductive cloning is the artificial reproduction in the laboratory of a genetically accurate copy of any living creature. For example, Dolly Lamb is an example of such a cloning of a large animal. In many countries of the world, human reproductive cloning for the purpose of obtaining clone children is prohibited by law. Reproductive cloning can be carried out in two ways: by separating the embryo's blastomeres at the first stages of its development (first week), as a result of which twins are born, or by transferring the nucleus of a somatic (nonreproductive) cell to an egg cell, from which previously removed its own nucleus, and with its subsequent implantation into the body of a surrogate mother. Therapeutic cloning (cell reproduction) is the same as reproductive cloning, but with an embryo growth period limited to 14 days. After a 14-day period, the central nervous system and conglomerate of cells (embryo, blastocyst) begin to develop in embryonic cells; and it should already be considered a living creature. For example, in the United Kingdom free use for scientific research of live embryos, not older than 14 days of age, is allowed. Therefore, the cultivation of human tissues and organs for transplantation needs is a real and close opportunity to use the success of cloning in medicine. This is not about reproductive cloning, but about getting the tissues of human embryos for transplantation [18].

Let us consider in more detail the first option - human cloning. So, at the legislative level in Ukraine there is a ban on reproductive human cloning. The provisions of the Law of Ukraine "On the prohibition of human reproductive cloning" proclaims that, based on the principles of respect for a person, recognition of a person's worth, the need to protect human rights and freedoms, and given the insufficient study of the biological and social consequences of human cloning, a ban on human reproductive cloning is introduced in Ukraine. This law defines the cloning of a person: "as the creation of a person genetically identical to another living or dead person by transferring the female reproductive cell of the nucleus of the somatic cell of a person left without a nucleus". Also, this Law provides for a ban on the import into the territory of Ukraine and the export of cloned embryos from its territory [23]. The UN Universal Declaration on the Human Genome and Human Rights, the Additional Protocol on the Prohibition of Human Cloning to the Council of Europe Convention on Human Rights and Biomedicine, the European Union Charter of Fundamental Rights also call for the prohibition of reproductive cloning of humans, that is, obtaining their genetic copies. The legislative application of the prohibition of cloning is most common in the legislation of European countries. 


\subsection{The right to donate.}

The Civil Code of Ukraine proclaims that an adult capable natural person has the right to be a donor of blood, its components, as well as organs and other anatomical materials and reproductive cells. Donation of blood, its components, organs and other anatomical materials, reproductive cells is carried out in accordance with the law. The capture of organs and other anatomical materials from the body of a deceased individual is not allowed, except in cases and in the manner prescribed by law. An individual may give written consent to the donation of his organs and other anatomical materials in case of his death or prohibit him. The donor must be unknown to the recipient, and the recipient - to the donor's family, unless the recipient and donor are married or are close relatives (Art. 290) [8]. The Law of Ukraine "On Donation of Blood and Its Components" determines that donation of blood and its components is a voluntary act of the will of a person, is to donate blood or its components for further direct use for treatment, manufacture of appropriate drugs or use in scientific research. A donor can be any capable citizen of Ukraine over 18 years of age who has undergone an appropriate medical examination and who has no contraindications. The collection of blood and (or) its components from a donor is permitted only on condition that donors are not harmed by their health (Art. 2) [2].

\subsection{Human right to transplant.}

According to the provisions of the Law of Ukraine "About application of transplantation of anatomical materials to humans", the term "transplantation" is defined as a special treatment method, consisting in the transplantation of human anatomical material from a donor to a recipient and is aimed at restoring human health (Art. 1). The Law of Ukraine "On the application of transplantation of anatomical materials to humans" applies to the transplantation of anatomical materials to humans, the implementation of activities related to transplantation, obtaining human anatomical materials for the manufacture of bioimplants, determining the conditions for the use of xenografts (Art.3). Transplantation is used exclusively in the presence of medical indications and is carried out in accordance with industry standards in the field of healthcare with the consent of an objectively informed competent person (recipient) (Art.13) [1].

\subsection{The right to provide medical care to persons who require a change (correction) of gender.}

In Ukraine, the change (correction) of gender is provided for in Art. 51 "Fundamentals of the legislation of Ukraine on health care" 1992. This Law says: "At the request of the patient, in accordance with the biomedical and socio-psychological indications that are established by the central executive body, which ensures the formation of the state policy in the field of health protection, he can be changed through medical intervention in health facilities (correction) of his gender". A person who underwent a change in gender is issued a medical certificate, on the basis of which the question of the corresponding changes in its legal status is further resolved (Art. 51)[14]. 


\section{Conclusions}

In order to further develop legislation regulating the formation of an innovative legal environment in the healthcare sector, it is necessary: (1) the introduction of effective mechanisms to protect human and civil rights and freedoms for innovation in the healthcare sector; (2) develop and adopt amendments to legislation that reduce corruption risks in the healthcare sector; (3) to adopt a single special legislative act that would regulate the rights of patients in the field of healthcare; (4) bringing national health legislation in line with European Union legislation on health and the protection of human rights to innovation; (5) carrying out scientific research and technological development in order to improve the quality of the provided medical services. On the part of the state in the field of health protection of Ukraine on innovations, we believe that it is advisable to direct efforts to the creation and improvement of such types of them that can significantly improve the processes of providing medical services: changing the way consumers purchase and use medical care, creating innovative technologies and introducing technological processes that contribute to the development of new medical products and medicines. It should also be borne in mind that Ukraine's healthcare sector in relation to innovative technologies acts as a developing country, equal to the advanced achievements of European states. This fact forces us to pay close attention to foreign experience in the field of legal regulation of innovation and innovation in the healthcare sector in the context of the patient's right to innovation.

Realization of the rights of patients to innovations in the healthcare sector is an important stage in the development of the state and a priority direction of state policy. The introduction of effective innovative models in the health sector in the context of patient rights will improve the availability and quality of the provision of medical services. An important element in the implementation of innovative technologies in the healthcare sector is the regulatory framework, which must comply with international standards. The rights of patients to innovations in the healthcare field should be based on the basic principles of law and be carried out using medical information systems and communication technologies. The human right to innovate in the health sector includes: (1) the right to a biomedical experiment; (2) the right to assisted reproductive technologies; (3) the right to donate blood and its components; (4) the right to transplant organs and anatomical materials; (5) the right to therapeutic cloning; (6) the right to correct (change) sex; (7) the right to virtual reality.

\section{References}

1. About application of transplantation of anatomic materials to humans: Law of Ukraine № 2427-VIII of 17 May, 2018. Information of the Verkhovna Rada, 2018, No. 28, Article 232.

2. About Donation of Blood and Its Components: Law of Ukraine No. 239/95-VR of 23 June, 1995. Information of the Verkhovna Rada of Ukraine. 1995. № 23. Art. 183.

3. About innovative activity: Law of Ukraine № 40-IV of 04 July, 2002. Information of the Verkhovna Rada of Ukraine . 2002, № 36, Art.266.

4. About priority directions of innovative activity in Ukraine: Law of Ukraine № 3715-VI of 08 September, 2011. Information of the Verkhovna Rada of Ukraine, 2012, № 19-20, p.166.

5. Allen, L. N., \& Christie, G. P. (2016). The emergence of personalized health technology. Journal of medical Internet research, 18(5), e99. 
6. Bayram, M., Springer, S., Garvey, C. K. \& Özdemir V.(2020) COVID-19 Digital Health Innovation Policy: A Portal to Alternative Futures in the Making. OMICS: A Journal of Integrative Biology.abead of printhttp://doi.org/10.1089/omi.2020.0089

7. Berzina, A. B. (2018). Legal regulation of medical and biological experiments in Ukraine. Comparative and analytical law ,6, 92-95. URL. http://www.pap.in.ua/6_2018/24.pdf

8. Civil Code of Ukraine: Law of Ukraine No. 435 -IV of 16 January, 2003. Information of the Verkhovna Rada of Ukraine. 2003. №№ 40-44. Art. 356.

9. Constitution of Ukraine: Law of Ukraine No 254к/96 of 28 June, 1996. Information of the Verkhovna Rada of Ukraine. № 30. Art. 141.

10. Criminal code of Ukraine: Law of Ukraine № 2341-III of 5 April, 2001. Information of the Verkhovna Rada of Ukraine, 2001, № 25-26, Art.131.

11. Danko, V.V. (2019) Improving the management system of health care facilities on an innovative basis. Scientific notes of Tavriy a National University named after VI Vernadsky. Series: Economics and Management, 30 (69), 2, pp. 102-110.

12. Dutko A. O., Zabolotna M. R. (2016) Individual reproductive rights: essence, concept and classification. Scientific Bulletin of Lviv State University of Internal Affairs, 3, 86-90.

13. European Charter of Patients' Rights: International document dated 15.11.2002. URL: https://phc.org.ua/sites/default/files/uploads/files/hartia.pdf

14. Fundamentals of Ukrainian legislation on health care: Law of Ukraine No. 2801-XII of 19 November, 1992. Information of the Verkhovna Rada of Ukraine.1993. № 4. Art. 19.

15. Gorban, A. E. (2015). Model of optimization of management of innovative activity in the field of health care of Ukraine. Actual problems of modern medicine:Bulletin of the Ukrainian Medical Dental Academy, 15 (3-2 (51)).

16. Juma, C. (2010). African health innovation systems: preface. BMC International Health and Human Rights, 10, I1 https://doi.org/10.1186/1472-698X-10-S1-I1

17. Kela-Madar, N., \& Kela, I. (2019). The Machine-Human Collaboration in Healthcare Innovation. In Toward Super-Creativity-Improving Creativity in Humans, Machines, and Human-Machine Collaborations. IntechOpen. Retrieved from: https://intechopen.com

18. Korotky, T. (2002). Legal aspects of human cloning. Bulletin of the National Academy of Sciences of Ukraine, (3), 46-52.

19. Kovalenko, O.O. (2018). Patients' rights in health care as an element of public administration. Theory and practice of public administration, (2), 140-148.

20. Lavrik, M. A.(2005) To the theory of somatic rights human. Siberian Legal Bulletin, 3. 16-26.

21. Mochalov, $\mathrm{Yu}$ (2014). Innovative activity in the work of health care institutions. Practice of management of $a$ medical institution, 3, 28-38.

22. On Medicines: Law of Ukraine № 123/96-VR of 04 April, 1996. Information of the Verkhovna Rada of Ukraine, 1996, No. 22, Art. 86.

23. On the prohibition of human reproductive cloning: Law of Ukraine № 2231-IV of 14 December, 2004. Information of the Verkhovna Rada, 2005, No. 5, Art. 111.

24. Petrukh, O.A. (2019) State regulation of innovative development of the sphere healthcare of Ukraine (Thesis PhD). Lviv , 246 p.

25. Popovich ,T. \& Shavarin, A. (2019). Sutnisnov napovnennya the fourth generation of human rights. Government, statehood and law, 12, 266-271.

26. Povaliy, S.I. (2011). Cloning in the context of the formation of somatic human rights. Bulletin of Zaporiabia National University, Juridical Sciences, 1, 49-54.

27. Shebanitz, D .M. (2015) Contemporary issues of the theory of "generations of human rights" in the context of European interstate integration. Scientific Bulletin of Uz̧hhorod National University. Law Series, 31 (1), 57-61.

28. Shekera, O.G. (2013) Safeguarding human rights in the medical field. Men's health, 2 (45), 22-24.

29. Shevchuk V.V. Improvement of state regulation of innovative development of the health care system of Ukraine: (Thesis PhD). Mykolaiv, 2017. 219 p.

30. Starovoitova, O.E. (2006) The legal mechanism for the implementation and protection of somatic human and civil rights in the Russian Federation: historical, legal and theoretical analysis: (Thesis PhD). St. Petersburg, 453 p. 
31. The family code of Ukraine: Law of Ukraine No. 2947-III of 10 January, 2002. Information of the Verkhovna Rada of Ukraine. № 21-22. Art. 135.

32. World Health Organization (2006). Reproductive Health Indicators: A guide to the development, interpretation and analysis of global monitoring. Geneva: World Health Organization, 63 p. Retrieved from: https://apps.who.int/iris/handle/10665/43185 